\title{
Local Wisdom in the Picture Storybook for Elementary School Students in Sukoharjo Regency
}

\author{
Veronika Unun Pratiwi ${ }^{1}$, Sarwiji Suwandi ${ }^{2}$ \\ ${ }^{I}$ Veteran Bangun Nusantara University, Sukoharjo, Indonesia \\ ${ }^{2}$ Postgraduate of Sebelas Maret University, Surakarta, Indonesia \\ pratiwiunun@yahoo.co.id,sarwijiswan@staff.uns.ac.id
}

\begin{abstract}
In teaching Indonesian language, the unification between language and culture is a really interesting source of study. The objectives of this study is to explore the identity of Gatotkaca character values of local wisdom found in the elementary school students' reading book in several elementary schools in Sukoharjo Regency. This study was designed with a qualitative descriptive research model with content analysis technique. The data and data sources were taken from an elementary school student's reading book Gatotkaca Satria from Pringgodani. The results revealed that the local wisdom indicators primarily found in the reading book of Gatotkaca Satria Pringgodani including values of patriotism and other values such as discipline, hard work, creativity, sovereignty, democracy, respect for achievement, companionship, peace-loving, love of reading, and care to environment, social security, and responsibility. Gatotkaca principally showed the attitudes that can motivate students to develop patriotic sense.
\end{abstract}

Keywords

elementary school students, picture story reading books, Gatotkaca; local wisdom

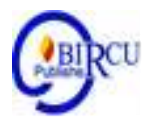

\section{Introduction}

Indonesian language is one of the subjects to be taught at the elementary school level. Some people think that it would be difficult to teach Indonesian language. This is because many teachers only teach Indonesian language traditionally and without other supporting materials, such as media, reading materials, and other literature. The presence of reading material other than textbooks is one of the efforts that teachers can find a way of making Indonesian language learning more compelling. Additional reading material can be taken from picture story books. According to Mitchell (2003:87), "Picture storybooks are books in which the picture and text are tightly intertwined. Neither the pictures nor the words are selfsufficient; they need each other to tell the story". This indicates that a picture story book is a typical book of images and words that do not stand alone, but depend on each other to become a unified story.

Elementary school children tend to enjoy pictures or colorful books. A picture story is a book that contains messages written in a light language style through illustrations mostly in form of pictures and writings and is fitted with pictures which become a single unit (Rothlein and Meinbach) (1991: 90). Themes are most frequently linked to individual / personal experiences in pictorial stories. Through his feelings and actions, the reader can easily describe himself by portraying the main characters.

Fadhilah \& Rahmawati (2020) explored the contents of local wisdom in student reading book published by KEMDIKBUD. The study showed that there were at least five contents of local knowledge in themed children's books, including culture, standards, ethics, beliefs and customs. Ratminingsih et al. (2020) found that Indonesian students have poor reading skills as a result of bad reading practices. They studied the effect of the 
storybooks from fairy tale textbooks focused on local culture by experimenting with student reading skills. Santoso \& Kosasih (2017) analyzed children's storybooks for elementary school students based on local wisdom of Tasikmalaya embroidery, their study focuses on providing explanations and designing children's storybooks based on local wisdom of Tasikmalaya embroidery that are used for fourth grade elementary school students as teaching materials.

The presence of a didactic content concerning knowledge of the Tasikmalaya embroidery craft is described by this teaching material. Murniayudi, et al (2019) evaluated the efficacy of local wisdom-based picture books in increasing the responsibility and social care of elementary school students in the fourth grade. Their study concluded that the local wisdom-based picture book is feasible based on the findings of validation by media experts and content experts as well as school trials. The previus related studies on picture storybook (Fadhilah \& Rahmawati, 2020; Ratminingsih, et al., 2020; Santoso \& Kosasih, 2017; Murniayudi, dkk, 2019) have studied the local wisdom underlying the school textbooks, the distinction of current study lies in the techniques of data analysis of each the previous study. This study exposes elements of local wisdom that are manifested in elementary school textbooks through content analysis techniques.

In the libraries of elementary schools, there are many available reading books, among which are the wayang tales, legends, and fable stories like the kancil story. Researchers chose wayang tales, particularly Gatotkaca Satria Pringgodani, because in the reading books they have elements of local wisdom, especially the local wisdom of the Javanese people, particularly Central Java (Ayatrohaedi, 1986). The reading book of Gatotkaca Satria Pringgodani is thus chosen as a mini-research material. The story of the Wayang character is one of the nation's legacies and should not be allowed to disappear without someone continuing to do so. One of the factors in the current generation's lack of understanding of puppet characters in this country is the lack of available media to provide information about Wayang characters like who Gatotkaca is? Where is this country? What's the greatness of it? What is his work for society? This information is important for younger generations to have before they begin to like the wayang performances. One of the preservation of this shadow art was to reach the younger generation with Gatotkaca Satria dari Pringgodani as an illustrated narrative. The selection of picture story books to to increase children's knowledge of wayang stories through Gatotkaca figures and the moral values and patriotic attitudes that are exemplified will be able to increase elementary school students' knowledge about local wisdom of noble Javanese culture.

Etymologically, local wisdom consists of two words, wisdom and local wisdom. Other local wisdom names include local wisdom, local knowledge, and local genius. Local wisdom in either case can be called local wisdom, as explained by the Ministry of Education and Culture, that local wisdom can be seen as a learning concept in schools to enhance the local potential of the regions in Indonesia. Various local wisdoms that have been maintained by ethnic groups in Indonesia are learned from nature, and consider everything that is good and useful, which they also learn from nature (Pandapotan and Silalahi, 2019). The objective of preserving local knowledge is to improve students' capacity to create and sustain their local wealth in Indonesia, notably in developing cognitive, affective and psychomotor aspects (Prasetyo, 2013; Aditama, 2010). Local wisdom is a social cultural value that shelters the complete complexity of the standards and conduct upheld.

Local knowledge within the individual or community is derived from the local genius of different ethnic groups. This intergenerational cultural rotation requires a middle generation that can understand the older generation and communicate with the next 
generation in light of the language they can easily understand. A temporary study of teachers and students in primary schools in Sukoharjo Regency has shown that teaching materials based on local wisdom are required using the chain pictures as media for Indonesian language lessons. Teachers and students alike need descriptive learning resources in order to enhance or significantly improve of Indonesian language learning among students that would improve learning results and build student character (Song et al, 2018).

By integrating Indonesian language teaching materials through local wisdom-based reading books, this challenge can be fixed by real efforts to maintain Sukoharjo Regency's noble values of local cultural wisdom. The role of reading books for elementary students is essential because the information provided can directly reach students through reading books carrying local knowledge. This local wisdom reading book could even summarize substances, approaches, models, methods, strategies, media, and learning evaluation, so that local wisdom needs to be incorporated into learning (Faizah, 2009).

The reading books used in this study include printed books. The material presentation is comprehensive, contextual, and nuanced by local cultural understanding with various images and colors, although only a few images. This book presents the key ideas and insights that the students of elementary schools of Sukoharjo regency have in Indonesian language lessons. This book was selected because it meets the age of the readers. This will lead students to learn, embrace and love their local cultural wisdom. Students learn more about their local cultural knowledge that can develop their love of the noble values of a culture, major global values that in turn improve nationalism.

The students' interest in reading rises with attractive teaching materials. This is consistent with Lestari (2013) which states that teaching materials are a collection of learning tools or instruments which contain systematically and attractively developed learning materials, methods, limitations and ways of evaluating. According to Dick, Carey and O'Carey (2009:230), there is a content in teaching materials which students have to learn to achieve those goals in print or made accessible by the teacher. Panen (2010) explains that in the teaching materials teaching materials that have different types of illustrations play a key role, because the illustrations will clarify concepts, messages, ideas or thoughts that have been communicated to the teaching material. Attractive graphics and good layouts and colorful and contextual images can render the materials of learning more interesting. In this case, the integration of character education in Indonesian elementary schools in Sukoharjo Regency by means of picture narrative media, based on local knowledge of the culture of Central Java, in particular Sukoharjo Regency. The problem formulations discussed are: how do you characterize the Gatotkaca's identity in the local values of the knowledge? The purpose of this study is to examine the identity of Gatotkaca characters in local wisdom in the reading of elementary students in Sukoharjo Regency.

For writers and compilers of books, mainly for teachers, this research is useful as an assessment material for the process of compiling Indonesian textbooks to increase the quality of the books; become a guide for teachers and students, i.e. as a key reference or an additional book. Furthermore, after understanding the content of the books being studied, elementary school students are expected to be more motivated to learn to use textbooks. For researchers, everyday life may be used to evaluate the quality of a pictorial textbook as additional research insights. 


\section{Research Methods}

The study was designed using a qualitative method. Qualitative research is a type of research that examines and understands the meaning of a number of people or groups of individuals on the basis of social problems (Creswell, 2016). The type of qualitative research used in this study is a case study. A case study is a study which analyzes a case in depth, collects complete information using various data collection procedures based on a predetermined time. This case may be an event, activity, process and program (Creswell, 2016). The data analysis technique used in this study is a content analysis that seeks to understand the symbolic messages in the document. The documents used in this study were handbook of elementary school students in Indonesian language classes. Content analysis is a study carried out in order to analyze the text or documents for drawing conclusions based on the context of their use.

In this study, the data collection technique uses content analysis. In the reading book of Gatotkaca Satria Pringgodani, this technique is used to collect data from documents and archives about the reality of local wisdom. Three significant application areas are identified in content analysis. In this study, the steps of data collection using the content analysis method include reading the Gatotkaca Satria Pringgodani reading book repeatedly to completely grasp its content; documenting words, phrases, and written items that describe the state of the object in line with the study topic; conducting literature studies on local wisdom in literature and other books which support the study. The data source used in this study is a text, namely data contained in Lustantini Septiningsih's reading book Gatotkaca Satria Pringgodani, which includes information on the description of Gatotkaca related to local wisdom. This study employed interview techniques in the reading book Gatotkaca Satria Pringgodani to obtain precise supporting data on Javanese local wisdom. Theoretical books, scientific journals, and related previous studies are other data sources in this study. To further validate the data, researchers used triangulation techniques (Paton, 1980: 100). In this study, the triangulation techniques used were source triangulation, triangulation of methods, and triangulation of theory. The source triangulation, which generates identical data from various sources of data.

\section{Results and Discussion}

\subsection{Local Wisdom-based Reading Books}

In the reading book Gatotkaca Satria Pringgodani said that that the figure of Gatotkaca is likely the most adored puppet character bychildren. It is indeed considered as the "wire muscle, iron bone" knight. His destiny as a mandraguna knight may be that he is the descendant of Bima, the Werkudara. Gatotkaca was born from Bima's marriage to Dewi Arimbi, who had a giant family background. Gatotkaca was a champion of the gods since childhood (the breed of gods). All the powers he had when the little Tetuka (baby name of Gatotkaca) was put into Candradimuka Crater and "mixed" with all the divine powers.

His role in helping the gods exterminate the wrath of wrath also gave him the ability to fly without worrying about the weather and not being spotted by his opponents. He also has the power that makes him safe from Aji Narantaka and Aji Brajamusti which can kill anything or anyone they hit. Gatotkaca is portrayed in Javanese puppetry as a complete (perfect) figure of a bureaucrat and a soldier. He never asks whether he should be offered by the state, but he is ready to sacrifice for the country and the state. As an outstanding state servant, several of his characters serve as examples. Gatotkaca also has flaws even 
though he has a divine lineage. Gatotkaca has in his navel a weakness. In the Baratayudha Epic, after being stabbed by a Kunta arrow, the arm of the King of Awangga Country, Adipati Karna, Gatotkaca died in a war in the Kurusetra field.

The requirements for the feasibility of the context of a reading book, as suggested by Mintowati (2003, p. 23, in Santoso, 2010, p. 63), are that three items must be considered as learning material in the selection of reading material, namely the students' level of complexity, cultural context, and attractiveness. In addition, three aspects that must be considered are listed in the Bookkeeping Center (2004, p. 16, Santoso, 2010, p. 63), namely: (1) ease of reading, (2) attractiveness, and (3) appropriateness. Text that does not conform to student characteristics may frustrate them or cause students to get bored in learning. These two factors can arise when the text that is being used as learning material for students is deemed too simple or too complicated. Reading books containing local wisdom for learning Indonesian in elementary schools as a solution to the above problems. With these guidelines, it is hoped that students will be interested in reading books based on local wisdom that can inspire and encourage students to learn without causing students to become dissatisfied and bored with learning, and can enhance the ability of students to process information, as well as their ability to provide responses and understanding of various problems that arise in any situation.

Learning reading skills in elementary schools as part of learning Indonesian language skills, one of which aims to teach students local wisdom to understand the content of reading texts. Learning to read is a way to provide teachers with appropriate instructions for preparing and developing students' reading skills. There are different reading learning activities, the teacher should collect data on ability levels, design appropriate instructions and tests, analyze the outcomes of continuous program design assessments, and document the students' reading skills development.

According to Calkins in Prioritas (2015, p. 98), teachers need to consider the concepts of reading activities, including that students need reading that can generate high interest, students need simple and explicit guidance and learning about the reading process and real skills, and should be given the opportunity to speak in response to the reading activities. On the basis of this description, learning reading skills enrich students' knowledge, the more reading material, the richer the vocabulary and ideas that can be expressed in oral and written communication. Teachers must therefore be intelligent in implementing various strategies and reading materials in accordance with their skills and needs, so that students can develop their reading and information processing skills.

\subsection{Indonesian Language Learning For Children through Wayang Character}

Indonesian Language subjects have actually been in elementary schools for a long time, because they are compulsory subjects. Indonesian Language Lessons in the 2013 Curriculum are text-based learning. Text is a complete expression of human thoughts in which it has a situation and context, the implementation of learning uses a scientific approach with an appropriate model. Language should be viewed as text not just a collection of words or rules of discussion, language is functional, which means that the use of language can never be separated from the context because the form of language used reflects the ideas, attitudes, values, and ideology of the user or user.

The art of wayang demonstrates local wisdom which is useful for constructing the character and identity of the Indonesian people illustrated by the characters in the wayang. People used wayang in ancient times as a means for learning about life, spirituality, literature, and art. Nowadays, puppets are considered obsolete, outdated and irrelevant to modern life. Wayang certainly includes a philosophy of life which can be a lesson to 
humans at any time. Soeroto highlighted the role of wayang as a religious ceremony, instead of the puppet itself (Mulyono, 1983: 33). Soeroto also claimed that wayang is a native Indonesian culture and closely linked to the worship of "Hyang" and that his plays are taken from stories that originated in India (Mulyono, 1983: 34). In response to the statement as to where the Wayang originated, this Wayang was discovered in Indonesia and in particular in Java, although the Wayang plays were taken from India.

Local wisdom includes a variety of a community's knowledge, viewpoints, values, and practices, both from previous generations and from different life experiences in the present, including from contact with other communities or cultures. Buwono X $(2009$, p. 1) states that by using cognition to behave and act on something, object, or event that occurs in a particular space, local wisdom is also understood as a human effort. In addition to being a reference to individual behavior, local wisdom is worthy of viewed as a continuum the life of a society full of civility so that it can be considered a collective intelligence. Local wisdom is an entity that incorporates aspects of collective intelligence and creativity to significantly decide human dignity in a community for the advancement of national civilization (Dwiyanto, 2009, p. 3). In the characterization of Gatotkaca, which is portrayed in the reading book Gatotkaca Satria Pringgodani by Lustantini Septiningsih, the following definition illustrates local wisdom. The local wisdom at issue includes:

\subsection{Characterization of the Figure}

The results of this study include the findings in the reading book explaining the identity of the characterization of Gatotkaca in local wisdom values in Lustantini Septiningsih's reading book Gatotkaca Satria Pringgodani and the results of informant interviews. The book tells of a Gathotkaca that tale "Gatotkaca Satria Pringgodani" describes the second son of Raden Wrekudara is Raden Gatotkaca. His mother in Pringgandani was a giant princess named Dewi Arimbi. Gatotkaca was a giant at the time of his birth, as no weapon could possibly cut his umbilical cord. Then, with Karna's weapon called Kunta, the umbilical cord can be cut, but the sheath went into the stomach of Gatotkaca, contributing to his supernatural powers. The baby Gatotkaca was cooked like a porridge in the Candradimuka crater by the will of the gods and packed with all its powers; thus Raden Gatotkaca is a muscular, iron-boned, bloody gala-gala that can fly in the clouds and stand on the clouds that cross. When flying in the air, Gatotkaca's pace is like lightning, and wild as lightning. His war power can pull his enemy's neck out by using it at an appropriate moment. Gatotkaca was proclaimed King of Pringgadani, and he was named a knight of Pringgadani, since descendants of the female side regulated the state government. Gatotkaca was killed by a Kunta weapon fired at Gatotkaca during the Baratayudha Battle. In the sky, as Gatotkaca hides. Gatotkaca fell from the sky and smashed Karna's train car. Gatotkaca was related to Dewi Pregiwa's brother, the daughter of Raden Arjuna.

Characteristics must be able to create a character image. This is where the stories can live. According to Satoto (1985: 24), characterisation is the process of presenting a character as a character in a play. Characteristics must be able to create a character image. Characterization is used in a variety of ways. The character can be revealed through: (a) actions, (b) speech or speech, (c) thoughts, feelings, and wills, (d) physical appearance, and (e) what he thinks, feels, or wants about himself or others. Waluyo (2003: 14) states that the character of the dialog will be manifested. The type of dialog and the color will describe the character. In the puppet, the characters already have a distinctive character, which is also supported by gestures, voices, length of dialogue, types of sentences and expressions used. 
In the Indonesian version, Gatotkaca is known as one of the knights who chose to compete. The Gatotkaca figure was always the main character in various puppetry plays before the Baratayuda war took place. In the Mahabharata puppet story, the ideal young character is Gatotkaca. Generally, the Javanese, Sundanese and Balinese associate Gatotkaca with the young persons. Gatotkaca is indeed a powerful young character with iron-reinforced wire veins, known as the iron-bone wire muscle, and has a physical condition that is resistant to various weapons. He is like a bionic actor in Hollywood films, following the life story of Gatotkaca. Even Gatotkaca was able to inherit his grandfather's Pringgondani Empire. Therefore, it comprises spiritual and heroic ideals that are very beneficial in this modern age.

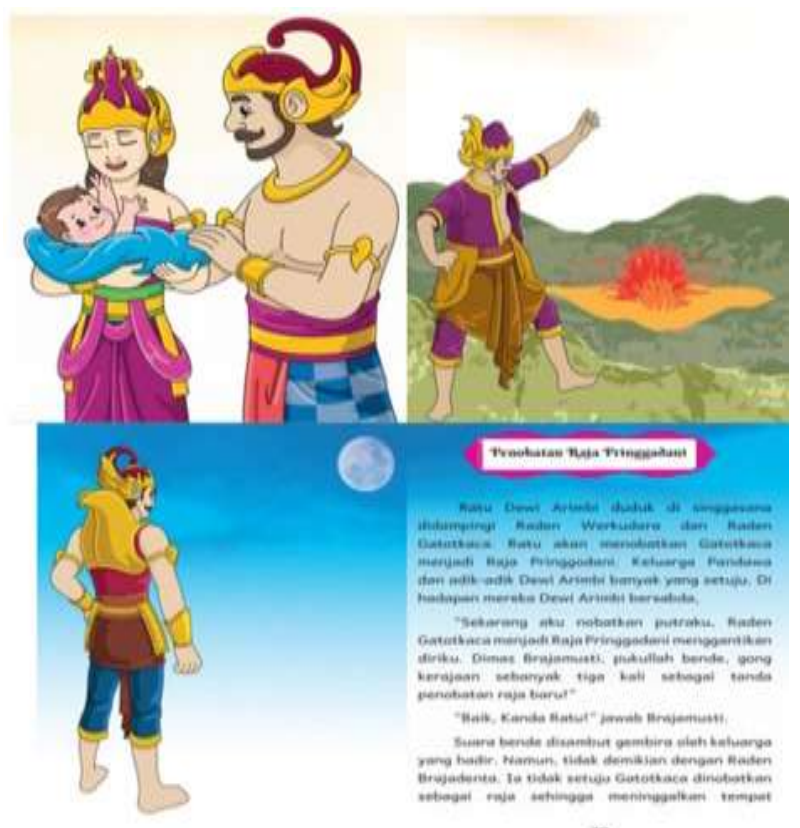

Figure 1. Illustration of the picture story book of Gatotkaca Satria Pringgodani

Gatotkaca is portrayed in Javanese puppetry as a complete (perfect) figure of a bureaucrat and a soldier. He never asks whether he should be offered by the state, but he is prepared to sacrifice for the country and the state. As an outstanding state servant, several of his characters serve as examples. Even though he has a divine lineage, Gatotkaca still has weaknesses. Gatotkaca has a weakness in his navel if Superman has a weakness for Krypton stones. In the Baratayudha Epic, after being stabbed by a Kunta arrow, the arm of the King of Awangga Country, Adipati Karna, Gatotkaca died in a war in the Kurusetra region. Linguistically, it is easy for the target audience, especially elementary school students, to grasp and understand the use of language in this storybook. The use of language is plain and clear, but it is possible to convey the message and meaning properly.

\subsection{Indicators of Local Wisdom in the Gatotkaca from Satria Pringgodani Storybook}

The objective of introducing Gatotkaca is to reintroduce puppet characters to the younger society so that the preservation of culture, the cultivation of good moral values and as a leader for the successor of the nation, are found mainly in the books on local knowledge in Gatotkaca Satria Pringgodani. The local wisdom of Gatotkaca's storybook reflects patriot ideals and other positive values such as discipline value, hard work, creativity, independence, democracy, obedience, friendly / communicative, peace-loving, a love for reading, respect for the environment, social responsibility. Patriotism is an 
appreciation of a real, direct home on the same level as clothing, food and shelter in today's slogan (Santosa, 1987: 202). The Greek term patriotic is derived from patriotism and it means homeland. Patriotism is a sense of loyalty and respect for the nation and the people. Patriotism can also be seen to be a sense of pride and gratitude in nation's customs, pride in the nation's heritage and a devotion to a shared sense of well-being.

In coping with their personal and social problems, elementary school children love picture stories because it helps them to get to know their personal and social problems. The picture stories catch the imaginations of children and their curiosity about supernatural issues; in addition to offering children a temporary break from the hustle and bustle of daily life, like most children these days who use gadget media excessively. Gatotkaca Satria Pringgodani's picture story is easily understood by children in elementary school age, and even children who are less capable of reading would understand the meaning through the pictures shown. Gatotkaca characters often do or say things in picture stories that intentionally inspire children to believe, include being patriotic. The character in the story of Gatotkaca is widely known as a figure with a strong physique, courage, generous heart, love for the land, so that he has become a hero with whom children can identify; in addition, the pictures in the illustrated stories are colorful and clear enough for children to understand.

There is a sense of pride in patriotism on behalf of the country and the state. It is also possible to refer to patriotism as state defending. As mentioned by Andryanto, who explained that the legislature and officials of a nation have compiled the principle of state security. In relation to their interests in efforts to preserve the life of a nation, this definition reveals the patriotism of an individual, a community, or all components of a country (Hurlock 1978; Andrianto, 2015: 27). In addition, Andryanto (2015: 28) emphasized that the attitude of defending the country is the resolve, attitude and behavior of people who, based on love for the country, are orderly, detailed, integrated and continuous. In essence, the consciousness of defending the state is the willingness of every person to serve the state and the willingness to sacrifice to defend the nation. It can be concluded that the characteristics of patriotism are responsible for the country's integrity and security, love for the country, dedication to the country, and willingness to sacrifice for the country in Gatotkaca, where the characteristics of patriotism are manifested.

\subsection{Responsible for the safety and integrity of the Motherland}

This attitude often attempts to defend the country's sovereignty from being divided. In defending many of the countries he loves, Gatotkaca has a responsible attitude toward the dignity of his homeland. The dignity of Jonggring Saloka is Gatotkaca's responsibility. Due to the attempt to attack the Gilingwesi troops led by a king named Prabu Kalapracona, Jonggring Saloka's integrity was threatened and had a governor named Patih Sekipu. Selfsacrifice will be the next aspect of patriotism. As a patriot, Gatotkaca was always willing to sacrifice for the nations or individuals he valued. The sacrifice of Gatotkaca for his countries and loved ones is homogeneous. The first self-sacrificing attitude of Gatotkaca occurred when he did not care about the big flames to save the Kendalisada hermitage.

\subsection{Love and Devoted to the Motherland}

The attitude of love and devotion to his homeland was also evidenced by Gatotkaca in various events. Since the Pringgandani Kingdom deserves a smart king who is likely to deliver the kingdom in a better direction, he was supposed to have love for the homeland. Gatotkaca always served his homeland as a king, namely Pringgandani. Gatotkaca is still 
trying to lead his kingdom in a better and more dignified way. The attitude of loving Gatotkaca's homeland is also manifested by retaining the sovereignty of the region. $\mathrm{He}$ always fought against somebody who would take control of his country. When looking for the lost Keris Pulanggeni belonging to Raden Pancawala, Gatotkaca embodied the attitude of love and devotion to his homeland. The crown prince of the Amarta kingdom is Raden Pancawala. Gatotkaca's love for his homeland made him much needed, not only by his homeland but also by his family.

\section{Conclusion}

The local wisdom indicators primarily found in the reading book of Gatotkaca Satria Pringgodani including values of patriotism and other values such as discipline, hard work, creativity, sovereignty, democracy, respect for achievement, companionship, peace-loving, love of reading, and care to environment, social security, and responsibility. Gatotkaca principally showed the attitudes that can motivate students to develop patriotic sense. To elementary school students, even those who might not be as capable of reading, can easily understand the picture story of the Gatotkaca Satria Pringgodani. In the picture story, Gatotkaca's characters often showed from the way he does or says things that inspire children, - for examples of being patriotic. Through the values and attitude of patriotism embodied in the character of Gatotkaca, it shows that this picture story book of Gatotkaca Satria Pringgodani is quite interesting to be taught to elementary school students for the story encourages a lot of positive meanings and partriotism. The patriotism of the Gatotka figures is quite successful in enhancing students' character in Indonesian language subject, which teaches them the good virtues the story of Gatotkaca Satria Pringgodani.

\section{References}

Abidin, Y. (2012). Pembelajaran Bahasa Berbasis Pendidikan Karakter. Bandung: Refika Aditama. Ahmad, H. A. (2010). Kearifan Lokal sebagai Landasan Pembangunan Bangsa. Bandung: Remaja Rosdakarya.

Andriyanto, T. Taufik. (2015). Paradigma Baru Bela Negara. Yogyakarta : Global Pustaka Utama.

Arditama, AY. ,Wardani, S ,Purwanti, E. , Hindarto, N. (2018).Storybook Influence on Science Concept Comprehension Through Curiosity of Fifth Grade Elementary School Student, Journal of Primary Education (JPE), 7 (1) (2018)

Asriati, N. (2012). Mengembangkan Karakter Peserta Didik Berbasis Kearifan Lokal Melalui Pembelajaran di Sekolah. Jurnal Pendidikan Sosiologi dan Humaniora. 3 (2), 106-119.

Ayatrohaedi. (1986). Kepribadian Budaya Bangsa (Local Genius). Jakarta: Pustaka Pelajar. Dick, W., Carey, L., O'Casey, J. (2009). The Systematic Design of Instruction, 7th Editions, Pearson Education Ltd., London.

Fadhilah, A.N., \& Rahmawati, L.E. (2020). Muatan Kearifan Lokal pada Buku Bacaan Siswa Terbitan KEMDIKBUD. Diglosi, Jurnal Kajian Bahasa, Sastra, dan Pengajarannya, 3 (3), 2020, pp. 3137-330

Faizah, Umi. Keefektifan Cerita Bergambar untuk Pendidikan Nilai dan Keterampilan Berbahasa dalam Pembelajaran Bahasa Indonesia, Jurnal Cakrawala Pendidikan, 3, (2009), DOI: https://doi.org/10.21831/cp.v3i3.302

Fajarini, U. (2014). Peranan Kearifan Lokal dalam Pendidikan Karakter. Jurnal Sosio Didaktika,1 (2): 123-130. 
Menteri Pendidikan dan Kebudayaan Republik Indonesia. (2016a). Peraturan Menteri Pendidikan dan Kebudayaan Republik Indonesia Nomor 8 Tahun 2016 tentang Buku yang Digunakan oleh Satuan Pendidikan. Jakarta: Menteri Pendidikan dan Kebudayaan Republik Indonesia.

Menteri Pendidikan dan Kebudayaan Republik Indonesia (2016b). Peraturan Menteri Pendidikan dan Kebudayaan Republik Indonesia Nomor 24 Tahun 2016 tentang Kompetensi Inti dan Kompetensi Dasar Pelajaran pada Kurikulum 2013 pada Pendidikan Dasar dan Pendidikan Menengah. Jakarta: Menteri Pendidikan dan Kebudayaan Republik Indonesia.

Mitchell, Diana. (2003). Children's Literature an Imitation to the Word. Mi-chigan State University.

Moleong, L. J. (2008). Metodologi Penelitian Kualitatif. Bandung: Remaja Rosdakarya.

Murniayudi, Heti and Sujarwo, Sujarwo (2019) Pengembangan Buku Cerita Bergambar Berbasis Kearifan Lokal untuk Meningkatkan Tanggung Jawab dan Peduli Sosial Siswa Kelas IV Sekolah Dasar. (S2 thesis), Program Pascasarjana

Pandapotan, S., and Silalahi, A. (2019). Social Capital as a Local Wisdom of Farmer in Managing Agricultural Resources in Lubuk Pakam Sub-district, Deli Serdang District. Budapest International Research and Critics Institute-Journal (BIRCIJournal). P. 469-476.

Law, Shu Yen (2012). Effective Strategies for Teaching Young Children Critical Thinking through Picture Book Reading: A Case Study in The New Zealand Context. (An Academic Thesis). Victoria University of Wellington, retrieved from: https://core.ac.uk/download/pdf/41337439.pdf

Lestari, Ika. (2013). Pengembangan Bahan Ajar Berbasis Kompetensi. Padang: Akademia Permata.

Panen, P., dan Purwanto. (2004). Penulisan Bahan Ajar. Jakarta: Ditjen Dikti Depdikbud.

Prasetyo, Zuhdan, K. (2013). Pembelajaran Sains Berbasis Kearifan Lokal. ProsidingSeminar Nasional Fisika dan Pendidikan Fisika. Surakarta: FKIPUNS.

Kementerian Pendidikan dan Kebudayaan. (2018).Permendikbud no 20 Tahun 2018 Tentang PPK bagi Pendidikan Formal.

Ratminingsih, N. M., Budasi, I. G., \& Kurnia, W. D. A. (2020). Local Culture-based Storybook and Its Effect on Reading Competence. International Journal of Instruction, 13, (2), 253268. https://doi.org/10.29333/iji.2020.13218a

Rothlein, Liz \& Meinbach, Anita Meyer. (1991). Literature Connection Using Children's Book in the Classroom. London: Foresman and Company

Santoso, S., \& Kosasih, S.A.E. (2017). Buku Cerita Anak Berbasis Kearifan Lokal Bordir Tasikmalaya untuk Siswa Sekolah Dasar. Pedidaktika, Jurnal Ilmiah Mahasiswa $\begin{array}{lllll}\text { Pendidikan Guru Sekolah } & \text { (2017), }\end{array}$ https://ejournal.upi.edu/index.php/pedadidaktika/article/view/7202/7596

Song, J., Han, K., Lee, D., Kim, S.W. (2018). "Is a picture really worth a thousand words?": A case study on classifying user attributes on Instagram. PlosOne Journal., October 5, 2018. https://doi.org/10.1371/journal.pone.0204938

Whatley, B. \& Whatley, B. S. (2010). Zoobots. Australia: Harper Collins

Yin, Robert K. (1994). Case Study Research. Thousand Oaks, London, New Delhi: SAGE Publications. 